\title{
Sodalicja Mariańska Akademików w Krakowie w latach 1891-1953*
}

I. W Krakowie w okresie międzywojennym istniało kilka stowarzyszeń młodzieżowych o profilu katolickim. Jednym z nich było Stowarzyszenie Młodzieży Akademickiej „Odrodzenie” przy Uniwersytecie Jagiellońskim. W latach 1919-1921 Stowarzyszenia Młodzieży Akademickiej „Odrodzenie” powstawały przy uniwersytetach w całym kraju. Od 1929 r. do nazwy Stowarzyszenia dodano przymiotnik „Katolickiej”. Jak dowodzą badacze dziejów warszawskiego Stowarzyszenia „Odrodzenie”, krakowskie „Odrodzenie” miało odmienny charakter, było organizacją wyrażającą poglądy skrajnie konserwatywne. Dopiero na przełomie 1921/22 r. powstało „Odrodzenie” Stowarzyszenie Młodzieży Akademickiej UJ w Krakowie, wpisujące się w nurt warszawskiego stowarzyszenia o tej samej nazwie, którego koła powstały także w Lublinie, Poznaniu, Wilnie czy we Lwowie. Stowarzyszenie w Krakowie powstało z połączenia wcześniej działającego w Krakowie „Odrodzenia” z krakowskim stowarzyszeniem „Polonia”.

Statut Stowarzyszenia Katolickiej Młodzieży Akademickiej „Odrodzenie” przy Uniwersytecie Jagiellońskim w Krakowie z 1937 r. ${ }^{2}$ wskazywał, że celem Stowarzyszenia było ukształtowanie członków umysłowo i moralnie wedle zasad katolickich, narodowych i państwowych. Każdy członek Stowarzyszenia (grupowało ono zarówno studentki jak i studentów Uniwersytetu Jagiellońskiego) musiał być Polakiem, katolikiem, nienależącym do żadnych stowarzy-

\footnotetext{
* Tekst powstał na podstawie badań przeprowadzonych podczas przygotowywania rozprawy doktorskiej na temat stowarzyszeń katolickich w Krakowie w latach 1918-1939 i stanowi jej fragment, poszerzony o lata po II wojnie światowej.

${ }^{1}$ K. Turowski, Historia Stowarzyszenia Katolickiej Młodzieży Akademickiej Odrodzenie, Warszawa 1987, s. 14, 65-67; Odrodzenie, [w:] „Dzwon Niedzielny”, R. X, nr 52, Kraków 1934, s. 878. Stowarzyszenie to zostało zatwierdzone w dniu 17 marca 1923 r., a jego kuratorem był dr Ludwik Piotrowicz, zob.: Archiwum Uniwersytetu Jagiellońskiego (w dalszej części pracy oznaczone jako AUJ), sygn. jedn. archiw.: S II 737 - wykaz stowarzyszeń działających na Uniwersytecie Jagiellońskim.

${ }^{2}$ Archiwum Państwowe w Krakowie (w dalszej części pracy oznaczone jako APKr), sygn. jedn. archiw.: StGKr 211, s. 339-347.
} 
szeń o ideologii sprzecznej z nurtem „Odrodzenia”. Członkowie dzieli się na kandydatów, członków zwyczajnych, wspierających i honorowych. Władzami Stowarzyszenia było Walne Zebranie, Komisja Rewizyjna, Zarząd i Sąd Koleżeński³

Wspomnieć trzeba również o stowarzyszeniu: Bratnia Pomoc Teologów UJ w Krakowie, które było organizacją samopomocową. Bractwo niosło pomoc materialną świadczoną swoim członkom przez Zarząd za pośrednictwem sekcji ${ }^{4}$.

Kolejnym krakowskim stowarzyszeniem akademickim działającym przy Uniwersytecie Jagiellońskim było Koło Misyjne Akademików Uniwersytetu Jagiellońskiego. Jego celem było naukowe zajmowanie się sprawami misyjnymi oraz rozpowszechnianie idei misyjnej. Członkiem zwyczajnym Koła mógł zostać każdy student Uniwersytetu Jagiellońskiego, katolik, przyjęty przez Zarząd ${ }^{5}$. Koło krakowskie należało do Związku Akademickich Kół Misyjnych w Polsce, którego protektorem był Prymas Polski ${ }^{6}$.

Pomimo mnogości stowarzyszeń związanych z Kościołem katolickim, istniejących od końca wieku XIX do wybuchu II wojny światowej w Krakowie, dużym zainteresowaniem krakowian cieszyły się sodalicje. Większość stowarzyszeń stawiała sobie konkretne cele - nabożeństwa, praktyki religijne, pełnienie dzieł miłosierdzia. Sodalicje zaś zajmowały się różnorodną działalnością dla wielu stanów i grup społecznych ${ }^{7}$. Znaczącą grupę społeczną stanowiła młodzież, która była szczególnie narażona na wpływy otoczenia, często niekorzystne. Dlatego też tworzono liczne stowarzyszenia starające się uchronić młodzież przed niebezpieczeństwami życia w mieście, a także niosące pomoc w potrzebie. W ten nurt wpisuje się Sodalicja Mariańska Akademików w Krakowie, która wraz z Sodalicją żeńską Akademiczek gromadziła młodzież wokół wartości katolickich. Podkreślenia wymaga fakt, że pierwszą sodalicją powstałą w XVI w. była właśnie sodalicja skupiająca młodzież ${ }^{8}$.

${ }^{3}$ Szerzej na temat działalności Stowarzyszenia Katolickiej Młodzieży Akademickiej „Odrodzenie" w Krakowie zob.: AUJ, sygn. jedn. archiw.: O 108/I.

${ }^{4}$ Archiwum Kurii Metropolitalnej w Krakowie (w dalszej części pracy oznaczone jako AKMKr), sygn. jedn. archiw.: ABS 358 - Bratnia Pomoc Teologów UJ 1937-1938, 1950.

${ }^{5}$ AKMKr, sygn. jedn. archiw.: ABS 363 - Stowarzyszenia różne; statuty, regulaminy, ustawy statut Koła Misyjnego Akademików Uniwersytetu Jagiellońskiego, teczka nr 65.

${ }^{6} \mathrm{AKMKr}$, sygn. jedn. archiw.: ABS 363 - Stowarzyszenia różne; statuty, regulaminy, ustawy statut Związu Akademickich Kót Misyjnych w Polsce, teczka nr 53.

${ }^{7}$ A. Wróblewski, Czem jest Sodalicya Maryańska? Słowo do Sodalicyi Panów we Lwowie, 1903, s. 3-5. „Przewodnik Sodalicyj Maryańskich” z 1914 r. wyróżnił zasadnicze typy sodalicji: młodzieży uczącej się, dorosłych skupionych, które dzieliły się na sodalicje inteligencji i na sodalicje robotnicze: mieszczan, młodzieży wiejskiej i włościan, w końcu wyróżnił sodalicje niemieszkających razem, np. panów i pań wiejskich, nauczycieli i nauczycielek wiejskich. Zob.: H. Haduch, Zasadnicze typy sodalicyi, [w:] „Przewodnik Sodalicyi Maryańskich złączonych kanonicznie z Sodalicyą Rzymską Prima Primaria zostających pod opieką zakonu OO. Jezuitów: Ustawy zasadnicze i sposób prowadzenia sodalicyi” oprac. H. Haduch, Kraków 1914, s. 215-230.

${ }^{8}$ Szerzej na ten temat zob.: F. Kwiatkowski, Sodalicje Marjańskie w stużbie Kościoła, Kraków 1935, s. 10-12. 
Dzięki rozpoczęciu formacji duchowej już w młodym wieku, sodalisi kończący edukację mogli swobodnie wstąpić do sodalicji męskich - Sodalicji Kupieckiej, Sodalicji Panów czy Sodalicji Inteligencji Męskiej i byli zdolni do podjęcia zobowiązań płynących z członkostwa w tych organizacjach. Głównym ośrodkiem sodalicyjnym $\mathrm{w}$ omawianym okresie stał się Lwów, gdzie w 1889 r. ojciec Stefan Bratkowski założył kongregację młodzieży. Jednakże również w Krakowie spotykamy liczne sodalicje mariańskie. Po przyjeździe do Krakowa w 1894 r. ojciec Bratkowski zreorganizował sodalicję akademicką działającą w Krakowie już od 1891 r., utworzył sodalicje młodzieży szkół średnich, pomocników handlowych, panów miejskich ${ }^{9}$. Z racji kościelnego charakteru, sodalicje nie podlegały ustawom państwowym regulującym prawa do stowarzyszania się. Natomiast sodalicje akademickie, z powodu ich szczególnego charakteru i podlegania z jednej strony władzy kościelnej a z drugiej władzy świeckiej - uniwersyteckiej, dostosowywały swoje statuty do wymogów ustawowych.

II. Austriacka ustawa o prawie stowarzyszania się z dnia 15 listopada 1867 r. ${ }^{10}$, obowiązująca w Krakowie po odzyskaniu w 1918 r. niepodległości, bezpośrednio nie wspominała o stowarzyszeniach akademickich. Według reskryptu ministra spraw wewnętrznych z dnia 1 czerwca 1876 r. istniejące w chwili wejścia w życie ustawy o prawie stowarzyszania się stowarzyszenia akademickie musiały albo dostosować się do jej wymogów w ciągu 3 miesięcy albo się rozwiązać. Stowarzyszenia akademickie powstałe później musiały być powoływane stosownie do omawianej ustawy. Reskrypt ministra wyznań i oświaty z dnia 20 czerwca 1876 r. stanowil, że stowarzyszenia nazywające się akademickimi lub zachowujące się jako takie, mogły składać się wyłącznie ze studentów ${ }^{11}$. Na podstawie ustawy z dnia 13 lipca 1920 r. o szkolach akademickich $^{12}$ władzą uprawnioną do zatwierdzania statutów i nadzoru nad stowarzyszeniami akademickimi były senaty szkół akademickich, a w pewnych wypadkach także Ministerstwo Wyznań Religijnych i Oświecenia Publicznego.

W 1933 r. zostało wydane rozporządzenie Ministra Wyznań Religijnych i Oświecenia Publicznego z dnia 30 kwietnia 1933 r. o stowarzyszeniach akademickich $^{13}$. Było to rozporządzenie, które regulowało wyłącznie szczególny typ organizacji, jakimi były stowarzyszenia akademickie. Tym samym do stowarzyszeń akademickich nie znajdowało zastosowania rozporządzenie

${ }^{9}$ J. Rostworowski, Przewodnik Sodalicyj Mariańskich złączonych kanonicznie z archisodalicją Rzymska zwana Prima Primaria, Kraków 1925, s. 29-30.

${ }^{10}$ Dz. u. p. Nr 134; tekst dostępny jest także w publikacji: J. Piwocki, W. Stesłowicz, J. Münz, Zbiór ustaw i rozporządzeń administracyjnych, t. I, Lwów 1909, s. 185-207.

${ }^{11}$ Ibidem, s. 191.

${ }^{12}$ Dz. U. z 1920 r., Nr 72, poz. 494, z późn. zm.

${ }^{13}$ Dz. U. z 1933 r., Nr 30, poz. 259. 
Prezydenta Rzeczypospolitej Polskiej z dnia 27 października 1932 r. Prawo o stowarzyszeniach ${ }^{14}$. Na podstawie rozporządzenia o stowarzyszeniach akademickich, stowarzyszenia te mogły zrzeszać wyłącznie studentów jednej szkoły i nie mogły być członkiem innego stowarzyszenia czy związku bez zgody Ministra Wyznań Religijnych i Oświecenia Publicznego. Stowarzyszenia akademickie musiały należeć do jednego z typów stowarzyszeń: naukowego, samopomocowego, sportowego, przyjaciół narodów, ideowo-wychowawczego czy kulturalno-towarzyskiego. Na wniosek zainteresowanego stowarzyszenia akademickiego wspomniany minister mógł nadać osobowość prawną takiemu stowarzyszeniu. Założycielami stowarzyszenia akademickiego samopomocowego musiało być nie mniej niż 50 studentów, a każdego innego - 20 studentów, którzy występowali z 3 egzemplarzami statutu i pisemnym podaniem do senatu akademickiego o zatwierdzenie statutu. Rozporządzenie dokładnie określało materię statutową, która w razie stwierdzenia przez senat akademicki braków, musiała zostać uzupełniona. Senatowi akademickiemu przysługiwało prawo odmowy zatwierdzenia statutu stowarzyszenia, jeżeli nie spełniało ono wymagań określonych rozporządzeniem lub ze względu na cel, ustrój lub działalność jego istnienie było niezgodne z przepisami prawa lub mogło zagrażać bezpieczeństwu, spokojowi, porządkowi publicznemu i dyscyplinie szkolnej bądź nie przynosiło korzyści ani studentom, ani szkole. Stowarzyszenie miało prawo odwołania się od decyzji za pośrednictwem rektora do Ministra Wyznań Religijnych i Oświecenia Publicznego w przeciągu 14 dni od doręczenia decyzji odmownej. Podobnie wszelkie zmiany postanowień statutu wymagały zatwierdzenia senatu uczelni, ale także sam senat mógł wprowadzać zmiany w statucie, jeśli uznał taką potrzebę.

Wybory do władz stowarzyszeń akademickich opierały się na zasadach tajności i bezpośredniości. W stowarzyszeniach akademickich o liczbie członków nieprzekraczającej 200 osób wybory odbywały się na walnych zebraniach, a decyzje podejmowano zwykłą większością głosów. W stowarzyszeniach liczniejszych niż 200 członków obowiązywała zasada proporcjonalności. Prawo kandydowania przysługiwało członkom stowarzyszenia o stażu członkowskim co najmniej rocznym. Rektor prowadził rejestr stowarzyszeń, które działały na obszarze danej szkoły. Naczelny nadzór i opiekę nad stowarzyszeniami akademickimi sprawował Minister Wyznań Religijnych i Oświecenia Publicznego, natomiast nadzór i opieka bezpośrednia spoczywała w rękach senatu akademickiego, który wykonywał ją poprzez kuratora stowarzyszenia, wskazanego przez rektora z grona nauczycieli. Kuratorowi przysługiwało szereg uprawnień. Musiał być on zawiadamiany o każdym zebraniu stowarzyszenia na 48 godzin przed planowanym terminem, z podaniem porządku dziennego do zatwierdzenia, na którego zmianę również musiał wyrazić zgo-

${ }^{14}$ Dz. U. z 1932 r., Nr 94, poz. 808, z późn. zm. 
dę, a w sytuacjach nagłych czas ten ulegał skróceniu do 24 godzin. Obecność kuratora była konieczna podczas walnych zebrań; w razie niemożności jego przybycia rektor delegował inną osobę. Nieważne były uchwały podjęte na walnym zebraniu, o którym nie poinformowano kuratora, które nakazał odroczyć lub w sprawie nieobjętej porządkiem dziennym pod nieobecność kuratora. Wśród licznych uprawnień kuratora znalazło się między innymi prawo usuwania wniosków wedle niego sprzecznych ze statutem lub prawem, czy też prawo zawieszania uchwał sprzecznych ze statutem stowarzyszenia, przepisami prawa lub interesami stowarzyszenia. Rektor dysponował prawem do usuwania z urzędów stowarzyszenia prezesa lub członków zarządu, jeżeli podejmowali działania sprzecznie z prawem, statutem lub zarządzeniami władz nadzorczych. Senatowi akademickiemu przysługiwało natomiast prawo czasowego zawieszania działalności stowarzyszenia akademickiego na wniosek rektora, na czas od 1 do 6 miesięcy lub rozwiązania stowarzyszenia w określonych przypadkach.

$\mathrm{Na}$ podstawie rozporządzenia z 1933 r. Ministrowi Wyznań Religijnych i Oświecenia Publicznego oraz władzom akademickim przysługiwało prawo kontroli finansowej i ogólnej stowarzyszenia akademickiego, które co roku miało obowiązek przedkładać rektorowi stosowne sprawozdania. W końcu rozporządzenie wyznaczyło termin do dnia 1 grudnia 1933 r. na dostosowanie się istniejących stowarzyszeń akademickich do nowych uregulowań. W razie nie zastosowania się do owych przepisów, stowarzyszenia te ulegały rozwiązaniu.

Drobne zmiany powyższego rozporządzenia nastąpiły w drodze rozporządzenia Ministra Wyznań Religijnych i Oświecenia Publicznego z dnia 16 stycznia 1934 r. $w$ sprawie zmiany postanowień rozporzadzenia Ministra Wyznań Religijnych i Oświecenia Publicznego z dnia 30 kwietnia 1933 r. o stowarzyszeniach akademickich ${ }^{15}$. Wśród najistotniejszych zmian znalazło się postanowienie zakazujące stowarzyszeniu, które nie uzyskało zatwierdzenia statutu, nie tylko działania, ale również używania nazwy, mogącej sugerować akademicki charakter. Po wtóre, od tej pory wybory do władz stowarzyszeń akademickich odbywały się w terminach wskazanych przez rektora corocznie w lutym lub marcu. W końcu, do pomocy w opiece nad stowarzyszeniami akademickimi postanowiono dopuścić decyzją Ministra Wyznań Religijnych i Oświecenia Publicznego instytucje społeczne, powołane do wspierania młodzieży akademickiej.

Kilka ważnych zmian w zakresie tworzenia i działania stowarzyszeń akademickich przyniosło nowe rozporządzenie Ministra Wyznań Religijnych i Oświecenia Publicznego z dnia 14 października 1937 r. o stowarzyszeniach akademickich $^{16}$. Już na samym początku nowego rozporządzenia pojawiła

${ }^{15}$ Dz. U. z 1934 r., Nr 6, poz. 46.

${ }^{16}$ Dz. U. z 1937 r., Nr 78, poz. 572. 
się zmieniona definicja stowarzyszenia akademickiego, do którego zaliczono także stowarzyszenia współpracy intelektualnej z innymi narodami (dawne stowarzyszenia przyjaciół narodów), religijne, oświatowe, artystyczne i dobroczynne. Wyraźnie zakazano zajmowania się stowarzyszeniom akademickim polityką. Wprowadzono możliwość tworzenia stowarzyszeń akademickich złożonych ze studentów więcej niż jednej szkoły, w przypadkach małej liczebności studentów określonej grupy czy specjalnego charakteru stowarzyszenia. Warunkiem było, aby członkowie takiego stowarzyszenia akademickiego uczęszczali do szkół w tej samej miejscowości oraz aby statut został zatwierdzony przez senaty wszystkich uczelni, do których uczęszczali członkowie. Ponadto, nowa regulacja zezwoliła na powstawanie stowarzyszeń akademickich skupiających osoby z określonego wydziału, z określonego trybu studiów, pochodzące z pewnej części kraju, osoby danego wyznania czy narodowości. Rozporządzenie zezwalało na tworzenie regulaminów np. sądu, biblioteki czy sekcji w stowarzyszeniu akademickim. Taki akt wymagał zatwierdzenia rektora po zaopiniowaniu przez kuratora. O ile poprzednie rozporządzenie dawało senatowi akademickiemu prawo odmowy zatwierdzenia statutu $\mathrm{w}$ razie stwierdzenia jego nieprawidłowości, o tyle nowa regulacja nakazywała mu takie postępowanie, wyraźnie uniezależniając tę decyzję od woli senatu. Również ograniczeniem władzy senatu akademickiego w odniesieniu do stowarzyszeń akademickich było wprowadzenie konieczności powiadomienia przez senat zainteresowanego stowarzyszenia o woli wprowadzenia zmian do jego statutu. Stowarzyszenia uzyskały prawo wypowiedzenia się w tej kwestii, zajęcia stanowiska, a dopiero w razie niekorzystnej decyzji podjętej wbrew woli stowarzyszenia, mogły się one odwołać. Zniknął odrębny rozdział rozporządzenia poświęcony kontroli finansowej i ogólnej nad stowarzyszeniami akademickimi, podobnie jak zniknęło postanowienie o naczelnym nadzorze nad stowarzyszeniami akademickimi Ministra Wyznań Religijnych i Oświecenia Publicznego. Senat akademicki uzyskał prawo samodzielnego podjęcia decyzji o zawieszeniu działalności stowarzyszenia na czas od 1 do 6 miesięcy czy rozwiązania stowarzyszenia, a dodatkowo otrzymał moc pozbawienia prawa korzystania przez stowarzyszenie, jego władze z pewnych świadczeń na czas określony lub na stałe ${ }^{17}$.

III. Początki Sodalicji Mariańskiej Krakowskich Akademików sięgają roku 1891. W dniu 11 lutego 1891 r. z inicjatywy Władysława Scipio, Ka-

${ }^{17}$ Szerzej na temat organizacji stowarzyszeń studentów Uniwersytetu Jagiellońskiego, w tym przepisów o stowarzyszeniach akademickich obejmujących studentów więcej niż jednej szkoły akademickiej wydanych przez Sekcje Nauki i Szkół Wyższych Ministerstwa Wyznań Religijnych i Oświecenia Publicznego z dnia 1 kwietnia 1922 r. czy przepisów normujących stosunek Najwyższej Władzy Akademickiej do działalności Stowarzyszeń Akademickich (uchwała Senatu Akademickiego UJ z dnia 18 czerwca 1927 r.) zob.: AUJ, sygn. jedn. archiw.: S II 736. 
zimierza Szeptyckiego, Władysława Stadnickiego, Antoniego Strzeleckiego, Zdzisława Sobańskiego, Wincentego Tyszkiewicza i Józefa Zanietowskiego doszło do zawiązania się Kongregacji Mariańskiej dla Uczniów Uniwersytetu Jagiellońskiego. W pierwszych latach działalności liczba członków nie była znaczna, ale dbano przede wszystkim o to, aby członkowie byli zdolni do wiernego wypełniania zobowiązań płynących z udziału w Kongregacji. W roku sprawozdawczym 1891/92 kongregacja liczyła zaledwie 23 sodalisów. W dniu 10 maja 1891 r. uchwalono statut Kongregacji, której patronami została Najświętsza Maryja Panna Gromniczna i św. Stanisław Kostka.

W XX w. organizacja została przemianowana z Kongregacji na Sodalicję, a statut Sodalicji Mariańskiej Akademików w Krakowie, zatwierdzony został przez senat uniwersytecki w $1928 \mathrm{r}^{18}{ }^{18}$ wskazywał, że Sodalicja była osobą prawną. Celem Stowarzyszenia było kształtowanie duchowe członków, wspieranie ich pracy naukowej, organizowanie im życia towarzyskiego oraz wzajemne pomaganie sobie sodalisów w potrzebie. Członkowie Sodalicji gromadzili się na wspólnych zebraniach i nabożeństwach, spełniali praktyki religijne indywidualnie i zbiorowo, działali w sekcjach. Sodalicja organizowała publiczne odczyty i akademie, prowadziła wydawnictwa oraz $\mathrm{w}$ miarę możności wspomagała materialnie członków.

Członkowie dzielili się na honorowych, zwyczajnych, nadzwyczajnych i kandydatów. Członkiem honorowym Sodalicji mogła zostać osoba zasłużona dla Stowarzyszenia, mianowana poprzez aklamację przez Walne Zebranie na wniosek Wydziału. Członek honorowy nie miał w stosunku do Sodalicji żadnych obowiązków. Przysługiwało mu prawo udziału w zebraniach Sodalicji tylko wówczas, gdy należał do składu Uniwersytetu Jagiellońskiego, natomiast $\mathrm{w}$ nabożeństwach sodalicyjnych mogli uczestniczyć wszyscy członkowie honorowi. O członkostwo zwyczajne mógł starać się każdy student lub wolny słuchacz Uniwersytetu Jagiellońskiego, praktykujący katolik przyjęty przez Wydział. Członkowie nadzwyczajni musieli spełniać wymogi uzyskania członkostwa zwyczajnego, ale gdy: ,[...] bądź dla ważnych powodów przebywają w miejscowości, gdzie nie ma sodalicji, bądź dla innych ważnych powodów biorą udział w życiu sodalicyjnym za zgodą i wedle wskazówek Wydziału"19. Kandydatem stawał się student lub słuchacz Uniwersytetu w Krakowie, katolik przyjęty w tym charakterze przez Wydział. Wydziałowi przysługiwało prawo odmówienia przyjęcia do Sodalicji członka zwyczajnego, nadzwyczajnego i kandydata bez podania przyczyn odmowy.

${ }^{18}$ AKMKr, sygn. jedn. archiw.: ABS 313 - Sodalicja Mariańska Akademików - statut Sodalicji Mariańskiej Akademików w Krakowie z 1928 r. Uprzednio Sodalicja uzyskała zatwierdzenie w dniu 15 listopada 1924 r., a jej kuratorem był Władysław Wolter, profesor nadzwyczajny prawa karnego. Zob.: AUJ, sygn. jedn. archiw.: S II 737.

${ }^{19}$ AKMKr, sygn. jedn. archiw.: ABS 313 - Sodalicja Mariańska Akademików - statut Sodalicji Mariańskiej Akademików w Krakowie z 1928 r. 
Do obowiązków członków zwyczajnych i kandydatów zaliczano: czynny udział w zebraniach i praktykach religijnych Sodalicji, zaznajomienie się z obowiązującymi przepisami sodalicyjnymi, rozpowszechnianie idei sodalicyjnej, udział $\mathrm{w}$ pracach przynajmniej jednej z sekcji, regularne opłacanie składek członkowskich oraz udzielanie się w solidarnych wystąpieniach Sodalicji na zewnątrz. Zakres obowiązków członków nadzwyczajnych zasadniczo był tożsamy z obowiązkami członków zwyczajnych, chyba że Wydział postanowił odmiennie. Członkom zwyczajnym i nadzwyczajnym przysługiwało prawo głosu, czynnego i biernego wyboru na urzędy sodalicyjne oraz prawo korzystania ze wszelkich świadczeń i urządzeń Sodalicji; uczestniczyli oni także w przywilejach i odpustach nadanych sodalicjom. Przysługiwało im uprawnienie do noszenia odznaki sodalicyjnej oraz prawo do przedstawiania kandydatów na urzędy obsadzane przez Walne Zebranie, z wyjątkiem trzech członków prezydium. Kandydaci mieli możliwość korzystania z urządzeń Sodalicji wedle postanowienia Wydziału, ale nie przysługiwało im ani prawo głosu, ani uprawnienie wyborcze. Nie mogli również nosić odznaki sodalicyjnej.

Władzami Sodalicji Mariańskiej Akademików były Wydział, Walne Zebranie, Komisja Kontrolująca i Sąd Koleżeński. Wydział składał się z moderatora - kapłana wyznaczanego przez władzę kościelną, prezesa, dwóch wiceprezesów i innych członków wybranych przez Walne Zgromadzenie oraz poprzedniego prezesa. Posiedzenia Wydziału miały charakter poufny. Prezes reprezentował Sodalicję i pilnował wykonywania uchwał Walnego Zebrania, któremu przewodniczył, podobnie jak zebraniom ogólnym. „Wiceprezesi zastępują prezesa podczas jego nieobecności według starszeństwa lub delegowani przez niego prowadzą przydzielone im agendy"20. Wydział miał kompetencję do kierowania Sodalicją i zajmowania się wszelkimi sprawami niezastrzeżonymi dla innych organów. Między innymi do Wydziału należało prawo dysponowania majątkiem, przedstawiania kandydatów na prezesa, dwóch wiceprezesów i 6 członków Wydziału, prawo kooptacji nowych członków Wydziału na miejsca zwolnione, z wyjątkiem funkcji prezesa, ukonstytuowania się poprzez wybór sekretarza, skarbnika, instruktora kandydatów, kierownika rejonów i innych członków oraz najmowania płatnych pracowników administracyjnych. Wydziałowi przysługiwało prawo powoływania sekcji, których przewodniczący wchodzili w skład Wydziału.

Walne Zebranie zwyczajne zwoływano w trzecim trymestrze każdego roku. Termin obrad i ich porządek określał Wydział, informując o tym na tydzień przed wyznaczonym terminem przez ogłoszenie na urzędowych tablicach informacyjnych Sodalicji. Zgromadzenie nadzwyczajne mogło zostać zwołane przez prezesa na podstawie uchwały Wydziału lub na żądanie Komisji Kontrolującej. Statut określał szczegółowe kompetencje Walnego

${ }^{20}$ Ibidem. 
Zebrania. Wśród uprawnień wyborczych znalazło się prawo wyboru prezesa, dwóch wiceprezesów (spośród 3 kandydatów wskazanych przez Wydział - kandydat z najwyższą liczbą głosów obejmował urząd prezesa, a pozostali stosownie do liczby głosów urząd pierwszego i drugiego wiceprezesa), 6 członków Wydziału, 3 członków Komisji Kontrolującej i 5 członków Sądu Koleżeńskiego oraz wybór członków honorowych przez aklamację na wniosek Wydziału. Wybory członków Wydziału miały charakter tajny. Walnemu Zebraniu przysługiwało prawo uchwalenia zmiany statutu na wniosek Wydziału, uchwalenia rezolucji oraz zatwierdzenia zamknięcia rachunkowego na podstawie sprawozdania Komisji Kontrolującej. Uchwały Walnego Zebrania zapadały zwykłą większością głosów członków zwyczajnych i nadzwyczajnych w głosowaniu jawnym, o ile statut nie stanowił inaczej. W pierwszym terminie głosowania kworum wynosiło co najmniej połowę członków zwyczajnych i nadzwyczajnych, a w drugim terminie każda liczba członków głosujących była władna podjąć wiążącą decyzję.

Komisja Kontrolująca powołana była do badania finansów Stowarzyszenia i na podstawie wyników swoich czynności formułowała wniosek w kwestii zamknięcia rachunkowego przedkładany Walnemu Zebraniu. Komisja złożona była z 3 członków, którzy nie mogli równocześnie pełnić funkcji w Wydziale i Sądzie Koleżeńskim.

Wspomniany Sąd Koleżeński składający się z 5 członków niebędących członkami ani Wydziału, ani Komisji Kontrolującej wybierał spośród swego grona przewodniczącego i uchwalał swój regulamin. Do kompetencji tego organu należało rozstrzyganie sporów osobistych pomiędzy członkami Sodalicji przekazanych mu do rozstrzygnięcia przez obie strony oraz spraw spornych pomiędzy członkami Sodalicji wynikających z życia sodalicyjnego oddanych pod jego jurysdykcję przez jedną ze stron sporu. Organem wykonawczym Sądu Koleżeńskiego był Wydział, który był zobowiązany do wymuszenia poszanowania orzeczeń tego Sądu na jego wniosek.

Majątek Sodalicji Mariańskiej Akademików stanowiły zapisane na niego nieruchomości i ruchomości. Dochody Sodalicja czerpała ze składek członków, subwencji rządowych i samorządowych, ofiar, zapisów, fundacji, ze środków uzyskanych z organizowanych imprez. Majątkiem zarządzał i dysponował Wydział z prawem kupna i sprzedaży, zaciągania pożyczek, przyjmowania i zrzekania się darowizn. W sprawach majątkowych Wydział został zobligowany statutem do zwrócenia się o pomoc do Koła Przyjaciół Sodalicji Mariańskiej Akademików, do którego należał każdorazowy kurator i moderator Sodalicji. Ponadto Wydział mógł w porozumieniu z Kołem Przyjaciół Sodalicji zlecić wszelkie czynności związane z zarządem majątkiem jednemu lub kilku członkom Koła, którzy w tym zakresie reprezentowali Sodalicję na zewnątrz. Z racji tego, że Sodalicja Męska Akademików prowadziła domy, statut wyraźnie podkreślał, że opłaty mieszkańców domów mieszkal- 
nych, wypoczynkowych czy sanatoriów miały być przeznaczane wyłącznie na utrzymanie tych lokali, a nie uzyskanie jakichkolwiek korzyści.

$\mathrm{Na}$ wypadek rozwiązania Sodalicji, statut przewidywał przejście jej majątku na cele młodzieży akademickiej, za pośrednictwem Komisji likwidacyjnej powołanej przez ostatni Wydział Sodalicji.

Po wejściu w życie rozporządzenia z 1933 r. o stowarzyszeniach akademickich statut Sodalicji Mariańskiej Akademików w Krakowie uległ zmianie. Nowe regulacje zostały zaakceptowane uchwałą senatu uniwersyteckiego w grudniu 1933 r., a przez władzę kościelną w lipcu 1934 r. ${ }^{21}$ Do ważniejszych zmian należy dodanie do nazwy Sodalicji nazwy uczelni: Sodalicja Mariańska Akademików Uniwersytetu Jagiellońskiego, której siedziba mieściła się przy ul. Kanoniczej $14 \mathrm{z}$ racji wymogu grupowania w ramach stowarzyszeń akademickich studentów jednej uczelni. Stowarzyszenie zostało określone jako ideowo-wychowawcze, zatwierdzone przez Kościół katolicki. Wyeksponowano instytucję moderatora wyznaczanego przez władzę kościelną. Poddano statut nie tylko zasadom prawa kanonicznego, ale również przepisom rozporządzenia dotyczącego stowarzyszeń akademickich. W kwestii zarządzania majątkiem statut zaostrzył procedurę zaciągania zobowiązań, odtąd konieczna była do tego uchwała Zarządu podpisana przez prezesa i opatrzona pieczęcią Sodalicji. Statut wyznaczył tryb rozwiązania Sodalicji, pozostawiając tę sprawę uchwale Walnego Zebrania podjętej większością 3/4 głosów przy obecności przynajmniej 2/3 liczby członków zwyczajnych i nadzwyczajnych.

Statut Sodalicji Mariańskiej Akademików Uniwersytetu Jagiellońskiego, nawet już po zmianach wprowadzonych po wejściu w życie rozporządzenia z 1933 r. zawierał odrębności w stosunku do ogólnego wzoru organizacji sodalicyjnej. Na pierwszy plan wysuwa się brak dostatecznego określenia uprawnień moderatora. Właściwie poza wspomnieniem, że taką osobę - księdza katolickiego - wyznaczała kompetentna władza kościelna, nic więcej statut nie mówił. Co więcej, włączył moderatora do Wydziału, ustanawiając go członkiem tego organu, podczas gdy rolą moderatora w sodalicjach było kierowanie nimi, zarządzanie. Czynności, które w sodalicjach należały do tego podmiotu, w Sodalicji Mariańskiej Akademików zostały rozdysponowane pomiędzy inne organy. Statut szczegółowo natomiast opisał zakres działań i środków podejmowanych przez Sodalicję, w tym zezwolił jej na prowadzenie wydawnictw czy innej działalności pozwalającej na udzielanie sodalisom pomocy materialnej. Członkostwo zwyczajne przysługiwało zarówno studentom jak i wolnym słuchaczom krakowskiego uniwersytetu. W całym statucie wyraźnie akcentowano rozróżnienie na członków zwyczajnych i nadzwyczajnych, podczas gdy ich uprawnienia były w zasadzie zbieżne. W odniesieniu

${ }^{21}$ AKMKr, sygn. jedn. archiw.: ABS 313 - Sodalicja Mariańska Akademików - statut Sodalicji Mariańskiej Akademików Uniwersytetu Jagiellońskiego z 1933 r. 
do Wydziału nie określono częstokrotności zwoływania jego posiedzeń, przyznając mu duże kompetencje w kwestiach finansowych. Ponadto, Wydział zyskał prerogatywę do przekazywania uprawnień majątkowych członkom Koła Przyjaciół Sodalicji, niejako osobom z zewnątrz. Można to jedynie thumaczyć faktem niedoświadczenia młodych sodalisów zasiadających w Wydziale i chęcią powierzenia tak ważnego zakresu spraw osobom starszym, doświadczonym, którzy byli członkami Koła Przyjaciół. Walne Zebranie zbierało się nie jak zazwyczaj w pierwszej połowie roku, ale w trzecim trymestrze, co związane było z czasem rozpoczęcia zajęć akademickich i inauguracją nowego roku akademickiego. Statut, określając kworum konieczne dla podjęcia przez Zebranie wiążącej decyzji, przewidział sytuację braku wskazanej liczby głosujących i zezwolił na głosowanie w drugim terminie bez względu na liczbę obecnych, ale nie określił, kiedy owo drugie głosowanie mogło się odbyć. Zezwalał również na rzadko stosowane głosowanie przez aklamację w sprawie wyboru członka honorowego. Sąd Koleżeński - organ rozjemczy, co interesujące mógł rozstrzygać nie tylko kwestie sporne wynikające z członkostwa w Sodalicji. Miał także prawo rozsądzać sprawy osobiste między sodalisami, jeżeli obie strony o to wnioskowały. Sprawa trybu rozwiązania Sodalicji została ustalona w zmienionym statucie z 1933 r., gdzie szczegółowo określono jaki organ i w jakiej procedurze mógł taką decyzję podjąć.

IV. W celu zachęcenia gimnazjalistów do wstępowania w szeregi Sodalicji Akademików Uniwersytetu Jagiellońskiego po rozpoczęciu przez nich studiów, sodalisi - mocą uchwały władz sodalicyjnych z dnia 5 lutego $1892 \mathrm{r}$. - mieli się zapisywać do „Czytelni polskiej młodzieży katolickiej”, z której głównie korzystali gimnazjaliści, aby tym samym mieć okazję do poszukiwania potencjalnych członków. Kongregacja wpisała się również do Towarzystwa św. Wincentego à Paulo w Krakowie ${ }^{22}$ oraz przystąpiła do Związku Kongregacji Mariańskich. Dzięki tym działaniom w roku sprawozdawczym 1895/96

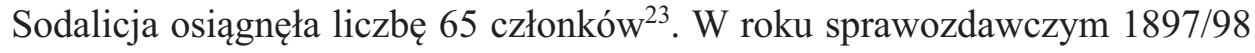
liczba sodalisów spadła do 60. Największą grupę stanowili studenci prawa. Po wakacjach ubyło 18 członków, z których część wyjechała za granicę, aby kontynuować naukę, część wstąpiła do wojska, 4 z nich zdecydowało się na życie w stanie duchownym. Kilku sodalisów, którzy skończyli studia prawnicze przeniosło się do sodalicji dla mężczyzn, wyjechało, część pracowała w biurach adwokackich, wspomagając także Sodalicję pomocą prawną ${ }^{24}$.

${ }^{22} \mathrm{~W}$ ramach Towarzystwa św. Wincentego à Paulo działała akademicka Konferencja pod wezwaniem św. Jana Kantego.

${ }^{23}$ Dziesięć lat istnienia krakowskiej Sodalicyi Maryańskiej Akademickiej 1891-1901, Kraków 1901, s. 9, 17.

${ }^{24}$ AKMKr, sygn. jedn. archiw.: ABS 273 - sprawozdanie Sodalicji Akademickiej pod wezwaniem Najświętszej Maryi Panny Gromnicznej i św. Stanisława Kostki za rok 1897/1898. 
Sodalicja powoli otwierała się na pracę społeczną, rozpoczynając w $1897 \mathrm{r}$. działalność sodalisów w „Opiece nad terminatorami”, gdzie uczyli gimnastyki, śpiewu, historii i literatury polskiej. Na przełomie wieków, w latach 18991900 Kongregacja akademicka uruchomiła Herbaciarnię. Była to odpowiedź na zagrożenie, jakie czyhało na młodzież przyjeżdżającą na naukę do Krakowa; zarówno to związane $\mathrm{z}$ biedą materialną, jak i to związane ze zdrowiem i moralnością. Celem Herbaciarni było dostarczanie uczniom gimnazjum bezpłatnych śniadań, a z czasem pracujący w niej sodalisi objęli opieką młodzież korzystającą z usług Herbaciarni ${ }^{25}$. W roku sprawozdawczym 1902/03 Herbaciarnia wydała ponad 18 tys. śniadań rozdawanych w klasztorze Sióstr Felicjanek, a od października 1902 r. w Zakładzie Stowarzyszenia św. Zyty przy ul. Mikołajskiej ${ }^{26}$. Herbaciarnia z czasem przekształciła się w sekcję opieki nad ubogą młodzieżą szkół średnich, w której pomoc świadczyły panie z Polskiego Związku Niewiast Katolickich. Statut sekcji wskazywał, że jej zadaniem była opieka moralna i materialna nad uczniami krakowskich szkół średnich, zależna od dostępnych środków finansowych. Sekcja przewidywała wydawanie bezpłatnych śniadań uczniom objętym opieką, prowadzenie dla nich biblioteki, organizowanie wycieczek, odwiedzanie chorych i udzielanie bezpłatnej pomocy lekarskiej, utrzymywanie w miarę możności sekcji szatni z mundurkami i bielizną, sprawdzanie postępów podopiecznych $\mathrm{w}$ nauce ${ }^{27}$. W ramach pomocy dla samych sodalisów działało Biuro informacyjne, które trudniło się wyszukiwaniem chętnych do skorzystania z korepetycji udzielanych przez sodalisów, wynajdywało mieszkania, pomagało w załatwieniu formalności na Uniwersytecie $^{28}$. W 1905 r. powołana została sekcja nauk apologetycznych, a rok późnej sekcja pogadanek środowych ${ }^{29}$. W roku akademickim 1909/10 Sodalicja liczyła 134 członków działających w 6 sekcjach: eucharystycznej, apologetycznej, pogadanek środowych, opieki nad ubogą młodzieżą szkół średnich, pracy społecznej oraz Konferencji św. Wincentego à Paulo. Sodalicja Mariańska Akademików w Krakowie roztaczała także opiekę nad terminatorami i czeladnikami pracującymi w Polskim Związku Katolickich Uczniów Rękodzielniczych, a opiekę lekarską sprawował bezpłatnie dr Józef Kownacki ${ }^{30}$.

Sodalicja współpracowała z Sodalicją Akademiczek, Towarzystwem im. ks. Piotra Skargi, Towarzystwem św. Wincentego á Paulo i akademickim

${ }^{25}$ Dziesięć lat istnienia krakowskiej Sodalicyi, s. 17-21.

${ }^{26} \mathrm{APKr}$, sygn. jedn. archiw.: Biblioteka 5565 - sprawozdanie z działalności Sodalicji Mariańskiej Akademików w Krakowie za rok sprawozdawczy 1902/1903, s. 10-11.

${ }^{27}$ APKr, sygn. jedn. archiw.: Biblioteka 5565 - sprawozdanie z działalności Sodalicji Mariańskiej Akademików w Krakowie za rok sprawozdawczy 1909/1910, s. 60-61.

${ }^{28}$ APKr, sygn. jedn. archiw.: Biblioteka 2967 - sprawozdanie Prefekta Kongregacji Mariańskiej Akademickiej za rok 1901/1902, s. 7, s. 11.

${ }^{29}$ APKr, sygn. jedn. archiw.: Biblioteka 12615 - dwudziestopięciolecie Akademickiej Sodalicyi Maryańskiej w Krakowie, s. 6-7.

${ }^{30}$ APKr, sygn. jedn. archiw.: StGKR 192, s. 75. 
stowarzyszeniem „Odrodzenie”. W roku sprawozdawczym 1924/25 Sodalicja Mariańska Akademików liczyła 107 członków. W Stowarzyszeniu działały sekcje: eucharystyczna, charytatywna, prelegentów, apologetyczna i samopomocowa. Ciekawe było wprowadzenie funkcji rejonowego, pełnionej przez członków Wydziału. Ich zadaniem było utrzymywanie bliższego kontaktu z grupą sodalisów. Rejonowy odpowiadał za wypełniane przez nich obowiązków sodalicyjnych. W 1924 r. ponowiono przerwane wojną starania o budowę domu im. ks. Stefana Bratkowskiego dla potrzebujących sodalisów. Wznowiono Komitet Budowy Domu, który zdecydował się zakupić na ten cel dom przy ul. Kanoniczej 14 za sumę pożyczonych 20 tys. dolarów ${ }^{31}$. W roku sprawozdawczym 1927/28 Sodalicja Akademicka liczyła około 300 członków i, jak sama podawała w sprawozdaniu, była największą sodalicją na terytorium Rzeczypospolitej Polskiej. Organizowała nabożeństwa akademickie w niedziele i dni świąteczne w kościele św. Anny, zalegalizowała jako osobne stowarzyszenie Koło Misyjne. W ramach Sodalicji działały sekcje: eucharystyczna, charytatywna współpracująca z Towarzystwem św. Wincentego à Paulo, koła prelegentów funkcjonującego w Towarzystwie im. ks. Piotra Skargi. Przy Sodalicji działały chór i biblioteka sodalicyjna. Sodalisami byli studenci wydziału filozoficznego w liczbie 128, prawniczego w liczbie 65, z wydziału lekarskiego w liczbie 24, rolniczego 7, teologicznego 1, ze studium farmaceutycznego 2, z Akademii Górniczej 17, ze Szkoły Przemysłowej 1, z Wyższego Studium Handlowego 5. Każdy z członków był zobowiązany do zapłaty składki miesięcznej w wysokości 50 gr. Część z nich została zwolniona z tego obowiązku lub obniżono im składkę o $50 \%$. Przychód Sodalicji nieznacznie przekroczył 20 tys. zł, przy czym prawie 15 tys. zł pochodziło z subwencji senatu Uniwersytetu Jagiellońskiego $^{32}$. W roku sprawozdawczym 1927/28 funkcję prezesa sprawował Tadeusz Romer, I wiceprzewodniczącym był Adam Przybos ${ }^{33}$, II wiceprzewodniczącym Marian Kusiak, sekretarzem był Stanisław Hestel, wicesekretarzem Bronisław Jaroń, skarbnikiem był Adam Jagielski, a obowiązki członków Wydziału pełnili: Bronisław Andrzejewski, Zygmunt Bauer, Jan Borowiec, Władysław Czapliński ${ }^{34}$, Aleksander Codello, Władysław Niessner, Zbigniew Preiss, Antoni Wadon. Moderatorem był ks. Romuald Moskała, jezuita ${ }^{35}$.

${ }^{31}$ APKr, sygn. jedn. archiw.: Biblioteka 5565 - sprawozdanie Sodalicji Mariańskiej Akademików w Krakowie za rok sprawozdawczy 1924/1925, s. 3-11.

${ }^{32}$ AKMKr, sygn. jedn. archiw.: ABS 313 - Sodalicja Mariańska Akademików UJ - sprawozdanie za rok sprawozdawczy 1927/1928.

${ }^{33}$ Adam Przyboś był później profesorem Wyższej Szkoły Pedagogicznej w Krakowie. Zob.: A. Pilch, Studenci Krakowa w Drugiej Rzeczypospolitej - ich ideowe, polityczne i spoleczne zaangażowanie, Kraków 2004, s. 118.

${ }^{34}$ Władysław Czapliński był później profesorem historii na Uniwersytecie Wrocławskim. Zob.: ibidem.

${ }^{35}$ AUJ, sygn. jedn. archiw.: S II 791, władze Sodalicji Mariańskiej Akademików UJ w roku sprawozdawczym 1927/1928. 
W latach 1928-1932 liczba członków wahała się od 288 do 350. Wśród nich przeważali studenci filozofii i prawa. W tym okresie dochody Sodalicji kształtowały się na poziomie 22-23 tys. zł, nie przekraczając progu 30 tys. $\mathrm{zł}^{36}$. W roku akademickim 1932/33 Sodalicja przeżywała czas trudności związanych z kryzysem ideologicznym młodzieży oraz niedopasowaniem dawnych form organizacyjnych do nowych form życia sodalicyjnego. Dużą rolę odegrał w tym okresie kryzys gospodarczy, który zmusił młodzież do jeszcze bardziej wytężonej pracy, wypełniającej ich codzienne życie i nie pozwalającej na systematyczną pracę w Sodalicji. Ponadto, organizacja Sodalicji nie przystawała ani do coraz szybciej rosnącej liczby członków, ani do zmian w systemie szkolnictwa, nakładających coraz więcej obowiązków na barki uczącej się młodzieży. Sodalicja prowadziła sekcje eucharystyczną, apologetyczną, charytatywną i prelegentów. Nadal działało Koło Misjologiczne Uniwersytetu Jagiellońskiego. Dochody Sodalicji Mariańskiej Akademików znacząco spadły w porównaniu do roku ubiegłego i wyniosły 10 223,30 zł, w tym z subwencji uniwersyteckiej pochodziło $9631,60 \mathrm{zt}^{37}$. Był to też rok zmian związanych z wprowadzeniem rozporządzenia o stowarzyszeniach akademickich i koniecznością ograniczenia członków Sodalicji wyłącznie do studentów Uniwersytetu Jagiellońskiego. Zlikwidowano w Sodalicji Akademików sekcję prelegentów, sekcję apologetyczną przekształcono w sekcję wykształcenia religijnego, sekcję eucharystyczną na krótko przemianowano na sekcję wyrobienia wewnętrznego, utworzono sekcję pracy naukowej: humanistycznej, prawniczej i przyrodniczo-lekarskiej. W 1934 r. senat Uniwersytetu Jagiellońskiego rozwiązał Koło samopomocy członków Akademickiej Sodalicji Mariańskiej, w miejsce którego Sodalicja utworzyła sekcję samopomocową ${ }^{38}$. Sekcja samopomocowa zarządzała domami sodalicyjnymi przy ul. Kanoniczej 14 i Mickiewicza 31, udzielała pożyczek, przyznawała stypendia, opiniowała wnioski o stypendia zagraniczne z fundacji im. hr. Potockiej ${ }^{39}$. Sekcja samopomocy rozdzielała mieszkania w domu sodalicyjnym im. ks. Stefana Bratkowskiego, prowadziła lub dzierżawiła kuchnię, udzielała pożyczek na mieszkanie, utrzymanie, czesne i inne potrzeby, dysponowała pewną liczbą łóżek w sanatorium ${ }^{40}$. Dom im. ks. Stefana Bratkowskiego przeznaczony był zasadniczo dla członków Sodalicji. Zarząd Domu przyjmował opłaty zróżnicowane w zależności od tego, ile osób zamieszkiwało pokój. W ramach opłaty, wahającej się miesięcznie od 17 do 35 zł, lokator otrzymywał mieszkanie

${ }^{36}$ APKr, sygn. jedn. archiw.: StGKr 210, s. 307-342; Biblioteka 5565 - sprawozdanie z działalności Sodalicji Mariańskiej Akademików w Krakowie za rok sprawozdawczy 1928/1929, 1930/1931, 1931/1932.

${ }^{37}$ AKMKr, sygn. jedn. archiw.: ABS 313 - Sodalicja Mariańska Akademików UJ - sprawozdanie za rok sprawozdawczy 1932/1933.

${ }^{38}$ APKr, sygn. jedn. archiw.: StGKr 210, s. 350-353.

${ }^{39}$ AKMKr, sygn. jedn. archiw.: ABS 313 - Sodalicja Mariańska Akademików UJ.

${ }^{40}$ APKr, sygn. jedn. archiw.: StGKr 210, s. 380-384. 
z opałem, oświetleniem i obsługą oraz podstawowym wyposażeniem. Regulamin Domu bardzo szczegółowo określał zasady korzystania z niego ${ }^{41}$.

Ważną zmianą było założenie, że przynależność do sekcji wyrobienia wewnętrznego, wykształcenia religijnego i pracy społecznej uzależniona była od stażu członkostwa w Sodalicji Akademików. W pierwszym roku sodalis mógł wybrać pracę albo w sekcji wyrobienia wewnętrznego albo wykształcenia religijnego. Sekcja społeczna była dla niego otwarta dopiero po odbyciu kursów obu poprzednich sekcji ${ }^{42}$.

W roku sprawozdawczym 1932/33 ogółem kandydatów chętnych do wstąpienia w szeregi Sodalicji było 47, z czego 19 wywodziło się z grona studentów prawa, 13 filozofii, 11 z wydziału lekarskiego, 3 z rolniczego i 1 z Wyższego Studium Handlowego ${ }^{43}$. Na końcu roku sprawozdawczego 1937/38 Sodalicja liczyła 235 członków. Składka miesięczna została obniżona do 30 gr., co i tak nie wpłynęło na zwiększenie liczby sodalisów uiszczających należności. $Z$ kwoty 634,50 zł, która winna była stanowić wpływy ze składek, wpłacono zaledwie 117,54 $\mathrm{zt}^{44}$. W ostatnim roku sprawozdawczym przed wybuchem II wojny światowej do Sodalicji zgłosiło się 38 kandydatów - $16 \mathrm{z}$ wydziału prawa, $14 \mathrm{z}$ wydziału filozoficznego, $4 \mathrm{z}$ lekarskiego, $3 \mathrm{z}$ rolniczego i $1 \mathrm{z}$ teologicznego. W tym roku również wstąpił do Sodalicji Mariańskiej Akademików Karol Wojtyła, jako student polonistyki, który ukończył gimnazjum w Wadowicach w 1938 r. W czasie nauki gimnazjalnej przyszły papież Jan Paweł II należał do Sodalicji Gimnazjalnej od grudnia 1936 r. ${ }^{45}$ Ogólnie liczba członków w latach 1933-1937 wahała się od 172 aż do 342 sodalisów $^{46}$. W 1939 r. Sodalicja liczyła 234 członków, a prezesem jej był student III roku prawa, Władysław Greal ${ }^{47}$.

V. Sodalicja Mariańska Akademików Uniwersytetu Jagiellońskiego po II wojnie światowej wznowiła swoją działalność ${ }^{48}$. Pierwsze powojenne Wal-

${ }^{41}$ AKMKr, sygn. jedn. archiw.: ABS 313 - Sodalicja Mariańska Akademików UJ - Regulamin Domu Sodalicji Mariańskiej Akademików Uniwersytetu Jagiellońskiego w Krakowie im. ks. St. Bratkowskiego.

${ }^{42}$ APKr, sygn. jedn. archiw.: Biblioteka 5565 - sprawozdanie Sodalicji Mariańskiej Akademików w Krakowie za rok sprawozdawczy 1932/1933, s. 12-13.

${ }^{43}$ AKMKr, sygn. jedn. archiw.: ABS 308 - Akademickie Sodalicje Mariańskie - deklaracje czlonków 1934-1938.

${ }^{44}$ AKMKr, sygn. jedn. archiw.: ABS 308 - Sodalicja Mariańska Akademików UJ - Całokształt życia sodalicyjnego 1937/1938.

${ }^{45}$ AKMKr, sygn. jedn. archiw.: ABS 308 - Akademickie Sodalicje Mariańskie - deklaracje członków 1934-1938. Zob. również: P. Płatek, Życiorys Jana Pawła II (skrót), Kraków 2003; A. Nowak, Jan Pawet II 1920-2005 ilustrowana biografia, Kraków 2010.

${ }^{46} \mathrm{APKr}$, sygn. jedn. archiw.: StGKr 210, s. 375.

${ }^{47}$ AUJ, sygn. jedn. archiw.: S II 791, nr $155 \mathrm{w}$ rejestrze stowarzyszeń akademickich.

${ }^{48} \mathrm{Z}$ okresu II wojny światowej pozostała księga główna Sodalicji, której zapisy rozpoczęto w styczniu 1931 r. i zakończono w 1941 r. Zob.: APKr, sygn. jedn. archiw.: 29/496/73. 
ne Zebranie miało miejsce w dniu 16 czerwca 1946 r., na którym na prezesa Sodalicji został wybrany Antoni Gleixner ${ }^{49}$. W 1946 r. Sodalicje Mariańskie Akademików i Akademiczek urządziły w dniu 27 października zebranie inauguracyjne, na które zaproszony został rektor Uniwersytetu Jagiellońskiego, prof. Franciszek Walter ${ }^{50}$. Sodalicja zwróciła się do Senatu uniwersyteckiego pismem z dnia 21 marca 1947 r. o zatwierdzenie statutu organizacji oraz ordynacji wyborczej. Ciągle obowiązywało jeszcze przedwojenne ustawodawstwo w tej mierze, z rozporządzeniem z 1937 r., o stowarzyszeniach akademickich włącznie. W piśmie tym założyciele podkreślili religijny charakter sodalicji i dołączając statut, wskazali również osoby odpowiedzialne ze strony Sodalicji za utrzymywanie kontaktów z władzami akademickimi. Pismo zostało opatrzone 20 podpisami członków, a 6 z nich było studentami prawa ${ }^{51}$.

Statut z 1947 r. stanowił, że protektorem może być każdy, jak się wyraził statut: „,należący do składu UJ”, kto był szczególnie zasłużony dla działalności Sodalicji. Członkowie dzieli się na zwyczajnych (mogli być to studenci, wolni słuchacze oraz doktoranci podlegający władzy uniwersyteckiej, o ile byli praktykującymi katolikami przyjętymi przez Zarząd), nadzwyczajnych oraz kandydatów. Władze w Sodalicji sprawowało: Walne Zebranie, Zarząd (już nie Wydział), Prezydium, Komisja kontrolująca i Sąd koleżeński. Uchwały Walnego Zebrania zapadały zwykłą większością głosów obecnych członków, ale już wyraźnie wskazano, wyłącznie zwyczajnych. Zmianie uległo przeznaczenie majątku po zlikwidowanym stowarzyszeniu, statut powojenny przewidywał przejście całego majątku rozwiązanej Sodalicji na cele Kościoła katolickiego reprezentowanego przez Kurię Metropolitalną w Krakowie ${ }^{52}$.

Statut Sodalicji został zatwierdzony na posiedzeniu Senatu UJ w dniu 10 września 1947 r., a na kuratora wyznaczono prof. Władysława Woltera. Jednakże Senat uzależnił wydanie swojej akceptacji dla statutu od wprowadzenia w nim kilku poprawek, w tym nakazał zmianę nazwy z: Sodalicja Mariańska Akademików Uniwersytetu Jagiellońskiego na Sodalicja Mariańska Akademików Studentów Uniwersytetu Jagiellońskiego ${ }^{53}$. Prof. Władysław Wolter zrezygnował z pełnienia funkcji kuratora już w październiku $1947 \mathrm{r}$. i Senat, przyjmując tę rezygnację w dniu 21 października 1947 r., na jego miejsce wskazał nowego kuratora, ks. dra Ignacego Różyckiego, który funk-

${ }^{49}$ AUJ, sygn. jedn. archiw.: S III 524, pismo z dnia 22 listopada 1949 r. od Sodalicji do sekretariatu rektoratu Uniwersytetu Jagiellońskiego.

50 Tamże, pismo z dnia 22 października $1946 \mathrm{r}$. Zaproszony na uroczystości inauguracyjne rektor, z racji niemożności wzięcia udziału w uroczystościach, zwrócił się pismem z dnia 24 października 1946 r. do ks. dziekana prof. Jana Krzemienieckiego z prośbą o zastąpienie go. Zob.: Ibidem, pismo z dnia 24 października $1946 \mathrm{r}$.

${ }^{51}$ Ibidem, pismo z dnia 21 marca $1947 \mathrm{r}$.

${ }^{52}$ Ibidem, statut Sodalicji Mariańskiej Akademików Studentów Uniwersytetu Jagiellońskiego.

${ }^{53}$ Ibidem, pismo zatwierdzające statut z $1947 \mathrm{r}$. 
cję piastował do końca istnienia Sodalicji ${ }^{54}$. W dniu 19 października 1947 r. odbyło się Walne Zebranie Założycielskie Sodalicji, na którym na prezesa został wybrany absolwent wydziału humanistycznego mgr Marian Danielec, a sekretarzem, członkiem Zarządu i członkiem Sądu koleżeńskiego zostali studenci prawa ${ }^{55}$. Na odbytym w dniu 22 lutego 1948 r. Walnym Zebraniu Sodalicji podniesiono sprzeciw wobec słowom krytyki kierowanym do Sodalicji, a dotyczącym zasadniczo przestarzałych metod pracy sodalicyjnej, podkreślając działania podejmowane przez organizację, których celem nadrzędnym było wyjście naprzeciw potrzebom akademickiego życia powojennego. Nowym prezesem został Józef Gniewniak, który od razu wystąpił z wnioskiem o złożenie hołdu księciu kardynałowi Adamowi Sapiesze wraz z prośbą o błogosławieństwo na nowy rok pracy. Wniosek ten został przyjęty przez aklamację. Protokół Walnego Zebrania podaje, że obecnych było na nim 45 członków i o. moderator ${ }^{56}$. Zaznaczyć trzeba, że Sodalicja w sposób wyraźny nawiązywała do swoich przedwojennych korzeni, gdyż numeracja Walnych Zebrań była ciągła i w 1948 r. odbyło się 57. zwyczajne zgromadzenie. Natomiast liczba członków Sodalicji była niewielka, biorąc pod uwagę liczbę członków Sodalicji przed wojną, sięgającą nieraz przeszło 300 sodalisów - na dzień 26 lutego 1948 r. było to 71 osób, w tym 12 studentów prawa ${ }^{57}$.

W dniu 20 stycznia 1953 r. na posiedzeniu Senatu akademickiego Uniwersytetu Jagiellońskiego ${ }^{58}$ ostatecznie przesądzono o rozwiązaniu Sodalicji Mariańskiej Akademików Studentów Uniwersytetu Jagiellońskiego w drodze uchwały Senatu. Referentem niniejszej sprawy na posiedzeniu Senatu był dr Bolesław Drobner ${ }^{59}$, zastępca rektora do spraw administracyjnych, późniejszy I sekretarz Komitetu Wojewódzkiego PZPR w Krakowie. Referent podnosił, że Sodalicja od 1947 r. nie wykazuje żadnej działalności, która byłaby wskazaniem dla jej dalszego funkcjonowania ${ }^{60}$. Powołując się na kuratora Sodali-

\footnotetext{
${ }^{54}$ Ibidem, pismo z dnia 6 listopada $1947 \mathrm{r}$.

${ }^{55}$ Ibidem, zawiadomienie z Sodalicji kierowane do Senatu Uniwersytetu Jagiellońskiego datowane na dzień 27 października $1947 \mathrm{r}$.

${ }^{56}$ Ibidem, protokół z 57 zwyczajnego Walnego Zebrania Sodalicji Mariańskiej Akademików Studentów UJ odbytego w dniu 22 lutego $1948 \mathrm{r}$.

${ }^{57}$ Ibidem, lista członków Sodalicji Mariańskiej Akademików Studentów Uniwersytetu Jagiellońskiego z dnia 26 lutego 1948 r. Sodalisami - studentami prawa byli: Władysław Bik, Józef Cabała, Antoni Gleixner, Józef Hasma, Ludwik Łysiak, Władysław Nowak, Jan Pachlewski, Stanisław Racia, Henryk Stupnicki, Czesław Świniarski, Antoni Woźmia, Stanisław Zabłoski.

${ }^{58}$ Ibidem, wypis z protokołu posiedzenia Senatu Akademickiego Uniwersytetu Jagiellońskiego z dnia 20 stycznia $1953 \mathrm{r}$.

${ }^{59}$ Szerzej na temat sylwetki Bolesława Drobnera zob.: M. Śliwa, Bolesław Drobner - szkic o działalności politycznej, Kraków 1984.

${ }^{60}$ Twierdzenie o braku aktywności Sodalicji Mariańskiej Akademików Studentów UJ w okresie od 1947 r., dające podstawy do zlikwidowania Sodalicji, nie znajduje oparcia w rzeczywistości. Stowarzyszenie to przesyłało do władz uniwersyteckich stosowne zawiadomienia o zamiarze odbycia Walnego Zebrania oraz przesyłało wyniki wyborów władz przeprowadzonych na owych zebraniach. Ponadto zachowało się w zbiorach Archiwum Uniwersytetu Jagiellońskiego pismo datowane
} 
cji, ks. prof. Ignacego Różyckiego, który nie wnosił zastrzeżeń w tej kwestii, oraz na zgodę dziekana wydziału teologicznego na likwidację stowarzyszenia, wskazywał na możliwość jego rozwiązania przez senat. Zwrócił także uwagę na sprawę budynku mieszczącego się przy ul. Kanoniczej 14 w Krakowie, który był siedzibą Sodalicji, a który w momencie jej likwidacji przejść miał zgodnie ze statutem Sodalicji w ręce Kurii Metropolitalnej w Krakowie. Referent podkreślił, że w budynku tym 5 pokoi zajmują zakłady naukowe UJ i w związku z tym Uniwersytet Jagielloński doszedł do porozumienia z Kurią krakowską i za roczną opłatą w wysokości 10 zł wynajął cały budynek, przejmując równocześnie wszelkie zobowiązania na nim ciążące. W budynku tym planowano urządzić „Dom Młodego Naukowca” - ,pomieszczenie dla pomocniczych sił naukowych Uniwersytetu". Po dyskusji na forum senackim, podjęto jednomyślnie uchwałę o rozwiązaniu Sodalicji Mariańskiej Akademików Studentów Uniwersytetu Jagiellońskiego i zatwierdzono umowę najmu nieruchomości przy ul. Kanoniczej $14^{61}$. Likwidatorem stowarzyszenia został dr Stanisław Władyka, który zawarł z Kurią umowę najmu budynku przy ul. Kanoniczej 14 na 10 lat ${ }^{62}$.

VI. Sodalicje mariańskie były stowarzyszeniami kościelnymi, erygowanymi przez właściwą władzę kościelną i przyłączanymi do archisodalicji w Rzymie. Ogólnie do sodalicji nie znajdywały zastosowania przepisy prawa państwowego dotyczące możliwości tworzenia stowarzyszeń. Jednakże sodalicje akademickie, jako organizacje podlegające nie tylko władzy duchowej jezuitów czy władzy diecezjalnej ${ }^{63}$, ale i władzy akademickiej, musiały dostosować swoje przepisy wewnętrzne - statuty, regulaminy - do wymogów prawodawstwa państwowego. W odrodzonej Polsce dopiero w 1933 r. wyda-

na dzień 11 grudnia 1947 r., w którym Sodalicja zwraca się z prośba do rektora Uniwersytetu Jagiellońskiego o wyrażenie zgody na zainstalowanie w budynku dziekanatu wydziału teologicznego gablotki dla umieszczania w niej informacji dla sodalisów. Stosowną zgodę Sodalicja uzyskała. Zob.: AUJ, sygn. jedn. archiw.: S III 524, pismo z dnia 11 grudnia 1947 r., a także zawiadomienie z dnia 19 października 1947 r. o odbyciu Walnego Założycielskiego Zebrania Sodalicji Akademików UJ; protokół z 57 Walnego Zebrania Sodalicji Mariańskiej Akademików UJ odbytego w dniu 22 lutego 1948 r.; pismo z dnia 22 listopada 1949 r. wskazujące na składy zarządów Sodalicji od pierwszego powojennego Walnego Zebrania do 1949 r. Można zatem sądzić, że podjęcie decyzji o rozwiązaniu Sodalicji Mariańskiej Akademików Studentów UJ warunkowane było czynnikami politycznymi, a nie opierało się na faktycznym zaprzestaniu aktywności przez to Stowarzyszenie.

${ }^{61}$ Ibidem, wypis z protokołu posiedzenia Senatu Akademickiego Uniwersytetu Jagiellońskiego z dnia 20 stycznia $1953 \mathrm{r}$.

${ }^{62}$ Ibidem, umowa najmu budynku przy ul. Kanoniczej 14 z 1953 r.

${ }^{63}$ Papież Leon XIII w dniu 7 marca 1825 r. wyraził zgodę, aby sodalicje powstawały dwutorowo - albo mogły działać przy domach i kościołach zakonu jezuitów i były wówczas kierowane przez duchownych jezuickich, albo mogły być zakładane przy innych kościołach czy kaplicach i podlegały zwierzchnikom diecezji. Obie grupy sodalicji łączył fakt przynależności do rzymskiej Prima Primaria, poprzez ich kanoniczną agregację. Zob.: J. Rostworowski, Przewodnik Sodalicyj Mariańskich, s. 21-22. 
no rozporządzenie dotyczące stowarzyszeń akademickich, a kolejna całościowa regulacja tego zagadnienia została ujęta również w ramy rozporządzenia w 1937 r. O ile akt z 1933 r. pozwalał na tworzenie stowarzyszeń akademickich składających się ze studentów tylko jednego ośrodka naukowego, o tyle rozporządzenie z $1937 \mathrm{r}$. zniosło pod pewnymi warunkami to ograniczenie. Dzięki przyjętemu rozwiązaniu mogło powstawać więcej tego typu organizacji, które pod rządami poprzedniego prawa nie mogły działać z racji braku odpowiedniej liczby członków pochodzących z jednej uczelni. Jednakże problem liczebności nie dotyczył Sodalicji Mariańskiej Akademików w Krakowie; w chwili powstania w 1891 r. w jej szeregach działało około 60 członków, a w okresie międzywojennym liczba ta znacznie wzrosła i w niektórych latach przekroczyła nawet 300. Sodalicja Mariańska Akademików Uniwersytetu Jagiellońskiego w Krakowie w pierwszej kolejności działała na rzecz swoich członków, propagując wśród nich zasady życia zgodnego z wiarą katolicką, wspomagając ich w potrzebie i jednocząc wokół tożsamej idei. Ale nie można również pominąć działalności Sodalicji i sodalisów skierowanej wobec ubogiej młodzieży szkół średnich, dla których otworzono Herbaciarnię, wydającą bezpłatne śniadania.

Po II wojnie światowej Sodalicja dostosowywała swoją pracę do powojennej rzeczywistości i, pomimo znacznie ograniczonej liczby członków w stosunku do lat przed wojną, wciąż była aktywnym stowarzyszeniem. Dlatego też podjęcie decyzji o zlikwidowaniu Sodalicji Mariańskiej Akademików Studentów Uniwersytetu Jagiellońskiego drogą uchwały Senatu akademickiego Uniwersytetu Jagiellońskiego w Krakowie w dniu 20 stycznia 1953 r. ${ }^{64}$ można uzasadniać jedynie niechęcią władz do istnienia i funkcjonowania stowarzyszeń mających związek z Kościołem katolickim, a już szczególnie organizacji kościelnych, erygowanych przez władze katolickie, jakimi były Sodalicje. Likwidacja tej Sodalicji wpisuje się w proces usuwania przez władze Polskiej Rzeczypospolitej Ludowej z życia publicznego wszelkich form wyrażania przez obywateli swoich przekonań religijnych.

${ }^{64}$ AKMKr, sygn. jedn. archiw.: ABS 345 - likwidacja Sodalicji Mariańskiej Akademików Uniwersytetu Jagiellońskiego. 